ISSN: $1412-4734$

E-ISSN: 2407-8646

Volume 18, Number 1, 2018

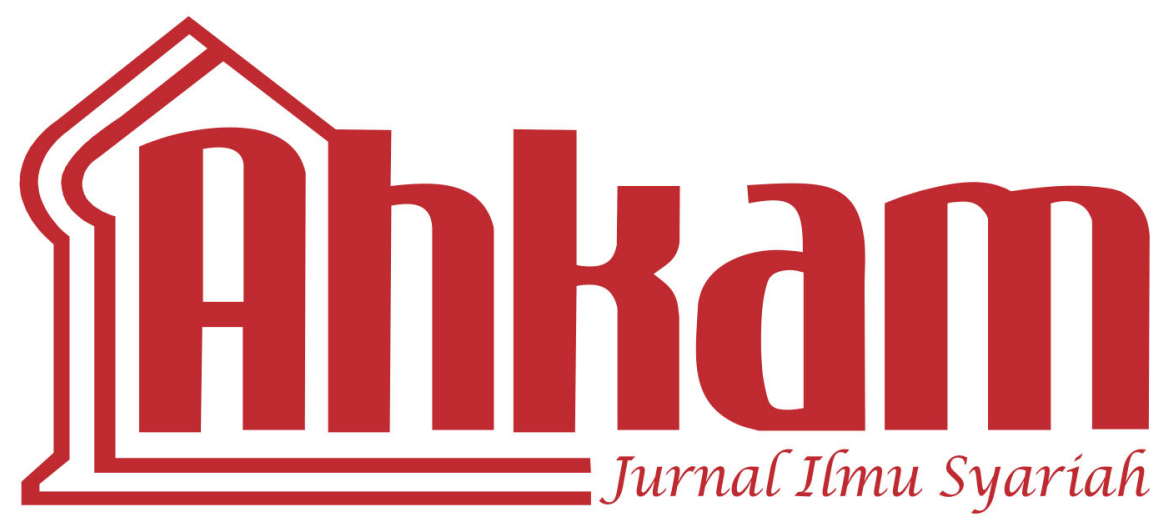

* Herdi Sahrasad \& Al Chaidar

Indonesian Terrorist, ISIS, and Globalization of Terror: A Perspective

* Hotnidah Nasution

Implementation of the Principle of Ultra Petitum Partium in Deciding Children Livelihood in Divorce Lawsuit in Religious Courts

* Havis Aravik, Choiriyah \& Saprida

Critical Study on the Legal Thinking of Muhammad Shahrur

* Nita Triana

Urgency of Arbitration Clause in Determining the Resolution of Sharia Economic Disputes

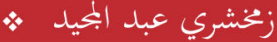

أهمية قوانين المصارف الشرعية في إنلدونيسيا (نظرية التقسير الموضوعى)

* Arrisman

Islamic Law And Business Ethics: Case Study of Forest Fires for Clearing the Lands 


\section{Mhliam}

Volume 18, Number 1, 2018

EDITOR-IN-CHIEF

Khamami Zada

EDITORS

Fathudin

Maman R Hakim

Windy Triana

Nur Hidayah

Ahmad Bahtiar

INTERNATIONAL EDITORIAL BOARD

Tim Lindsey (University of Melbourne Australia)

Nadirsyah Hosen (Monash University Australia)

Ahmad Hidayat Buang (Universiti Malaya Malaysia)

Raihanah Azahari (University Malay Malaysia)

Mark Elwen Cammack (Southwestern University)

Razeen Sappideen (University of Western Sydney)

Carolyn Sappideen (University of Western Sydney)

Nik Ahmad Kamal bin Nik Mahmod (International Islamic Universiti Malaysia)

Ahmad Tholabi Kharlie (UIN Syarif Hidayatullah Jakarta)

Muhammad Atho Mudzhar (UIN Syarif Hidayatullah Jakarta)

Masykuri Abdillah (UIN Syarif Hidayatullah Jakarta)

Muhammad Amin Suma (UIN Syarif Hidayatullah Jakarta)

M. Arsykal Salim GP (UIN Syarif Hidayatullah Jakarta)

Asep Saepudin Jahar (UIN Syarif Hidayatullah Jakarta)

ASSISTANT TO THE EDITORS

Kamal F. Musa

Erwin Hikmatiar

ENGLISH LANGUAGE ADVISOR

Bradley Holland

Umi Kulsum

ARABIC LANGUAGE ADVISOR

Amany Burhanudin Lubis

AHKAM has been accredited based on the determination of Director General of Research Reinforcement and Development, Research, and Technology Ministry of Higher Education of Republic of Indonesia, No. 36/a/E/KPT/2016 (valid until 2021). 
AHKAM Jurnal Ilmu Syariah (ISSN: 1412-4734) is a periodical scientific journal published by Faculty of Sharia and Law of Syarif Hidayatullah State Islamic University Jakarta in collaboration with Indonesian Scientist and Sharia Scholar Association (HISSI). This journal specifically examines the science of sharia and obtains to present various results of current and eminence scientific research. The administrators receive articles as contributions Sharia and Islamic law disciplines from scientists, scholars, professionals, and researchers to be published and disseminated.

\section{EDITORIAL OFFICE:}

Fakultas Syariah dan Hukum UIN Syarif Hidayatullah Jakarta

Jl. Ir. H. Juanda 95 Ciputat, Jakarta 15412

Telp. (+62-21) 74711537, Faks. (+62-21) 7491821

Website: http://journal.uinjkt.ac.id/index.php/ahkam/index

E-mail: Jurnal.ahkam@uinjkt.ac.id 


\section{Table of Contents}

1 Herdi Sahrasad \& Al Chaidar

Indonesian Terrorist, ISIS, and Globalization of Terror:

A Perspective

23 Hotnidah Nasution

Implementation of the Principle of Ultra Petitum Partium in Deciding Children Livelihood in Divorce Lawsuit in Religious Courts

43 Havis Aravik, Choiriyah \& Saprida

Critical Study on The Legal Thinking of Muhammad Shahrur

65 Nita Triana

Urgency of Arbitration Clause in Determining The Resolution of Sharia Economic Disputes

89

زخشري عبد المجيد

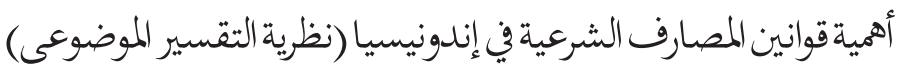


109 Arrisman

Islamic Law and Business Ethics: Case Study of Forest Fires for Clearing The Lands

125 Abdulmajeed Hassan-Bello

Riba and Islamic Banking, Examining the Practices of Jaiz Bank PLC, Nigeria

155 ISNaWATI Rais

Marriage Dispensation due to Extramarital Pregnancy: The Study on the Decision by the Religious Court of South Jakarta (2010-2011)

177 HaMZAH

Zakah Empowerment Optimization Through Baitul Ikhtiar Cooperation as an Effort in Poverty Alleviation in Bogor Regency

201 Abdul Muta'Ali

Israel and Palestine Conflict from Linguistics and Figh

Siyasah Perspective

219 Susiknan Azhari

Tracing the Concept of Fajr in the Islam Mosaic and Modern Science

233 Ahmad Sholihin Siregar

The Construction of Āyātul Aḥkām (Constructing the Selection Bases of Āyātul Aḅkàm) 


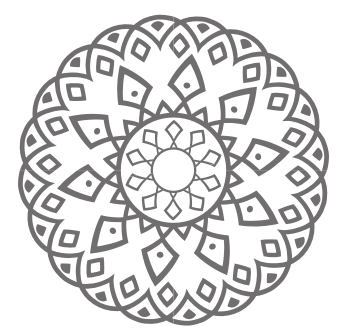

\title{
Tracing the Concept of FajR In the Islam Mosaic and Modern Science
}

\author{
Susiknan Azhari
}

\begin{abstract}
Abstrak: Paper ini berupaya menelusuri beberapa pandangan mengenai waktu Fajr yang akurat. Studi ini menemukan bahwa konsep-konsep yang berbeda mengenai Fajr dalam dunia Islam disebabkan oleh dua faktor: hadits Imamah Jibril yang terlalu umum dalam pemikiran dan cara-cara yang berbeda dalam memahami hadits "ghalas" dan "isfar" tanpa mempertimbangkan kondisi dan cuaca ketika hadits tersebut diucapkan. Selain itu, para astronom Muslim berfokus pada matahari dan mengabaikan pesan nash. Hal ini, pada gilirannya, menyebabakan kalim kebenaran.
\end{abstract}

Kata kunci: Ghalas, Isfar, jarak zenith ke matahari 
Abstract: This article is an attempt at tracing several points of view concerning the precise time of Fajr. The study suggests that different concepts of fajr in the world of Islam arose for two reasons: the Imamah Jibril hadith is too general in notion and the different ways in understanding the "ghalas" and "isfar" hadith without considering the conditioin and weather by the time the hadith was spoken. In addition, moslem astronomers focus on the empirical observation on the position of the sun and neglects the nas of the message. This, in turn, urges the truth claim.

Keywords: Ghalas, Isfar, distance of zenith of the sun

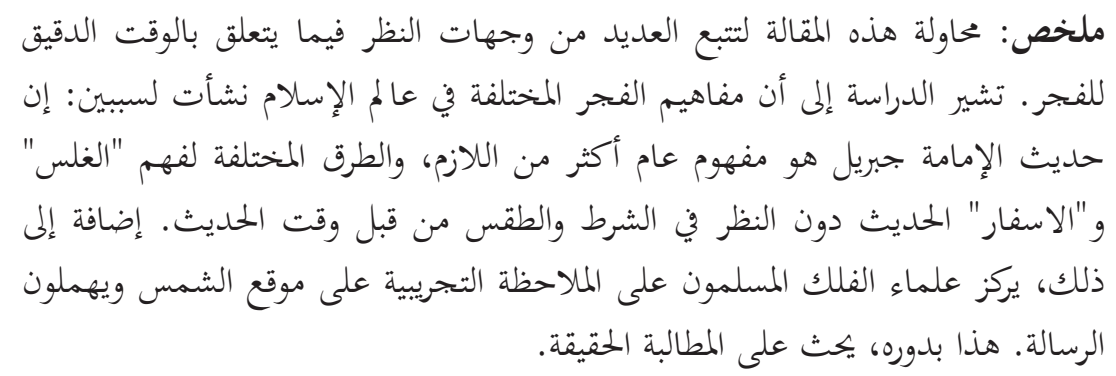

الكلمات المفتاحية: غلاس، إسفار، المسافة بين ذروة الشمس 


\section{Introduction}

In the Islamic astronomy study, determining the beginning of praying time is somewhat neglected. A research conducted by the writer reveals that the most popular Islamic atronomy study is the beginning of the month in lunar year instead of that of praying time. It is quite understandable since the issue concerns when the fasting month (Ramadan), Syawal and Zulhijah begin whereas praying time, no doubt, is considered final. The existance of praying time schedule in islam community proves the idea.

The moslem's belief in the start of praying time began to shake as Syaikh Mamduh Farhan al-Buhairi wrote an article entitled "Salah Kaprah Waktu Subub" (The Misconception of the Fajr-Praying Time) published in a series in a magazine Qiblati (Syaikh Mamduh al-Buhairi, 2010, Susiknan Azhari, 2012:323). The situation pushed moslem to hold discussions on the issue to review the accepted fajr-praying time.

Based on the writer's file, Hanafi S. Djamari had written an article entitled "Menelaah Kembali Awal Shalat Subuh" (Reviewing the fajrpraying time) published in Republika newspaper of May 21, 1999 before Syaikh Mamduh did. Hanafi, in his article, suggested a review on the concept of the distance of zenith of the sun at dawn. He claimed that $-18^{0}$ was relevant in recent time (Susiknan Azhari, 2012:323). Unfortunately, moslem did not respond accordingly.

Study on the concept of fajr had actually been conducted by some previous researchers who focused more on normative aspects which makes review on the concept is relevant. The review has to relate with the message of nas to both the geography and the weather as the hadith was conveyed. It has an important value as syar'i and science-based dawn is the target solusion.

\section{Praying Schedule in History}

There are some verses in the holy Quran discussing praying time, i.e. QS. An-Nisa' verse 103, QS. Al-Isra' verse 78, QS. Taha verse 130, and QS. Hud verse 114 in addition to a number of hadith from the prophet saw. A study by Jalaluddin al-Khanji informed us that, in Kutubut Tis'ah, as many as 543 hadith discussing praying time are on the list. The hadith are composed of 77 hadith from Sahih al-Bukhari, 
73 hadith from Sahih Muslim, 35 hadith from Sunan At-Tirmidzi, 131 hadith from Sunan an-Nasai, 45 hadith from Sunan Abu Daud, 40 hadith from Sunan Ibnu Majah, 30 hadith from Sunan ad-Darimi, 28 hadith from al-Muwatta' Imam Malik, and 84 hadith from al-Musannif Ibn Abi Syaibah.

Of the mentioned hadith, when assessing praying time, "Imamah Jibril" is the most popular (Wahbah Az-Zuhaily, 1989:1:506). From them, ulamas formulated praying time into five times: Zuhur, Asar, Magrib, Isyak, and Subuh. At the beginning of Islam, determining praying time was merely the task of muadzin who had to look at the position of the sun every time they were about to pray. When the hints in the hadith were seen, the beginning of praying time was due.

As time went by and interaction with other cultures particularly with Egypt, a nation with the tradition of observation compiled in the form of " $Z i j$ " (a table on astronomy), inspired them, moslem scientists started to arrange a schedule for praying time. David A. King, an Islamic astronomy manuscript researcher, as cited by Auni Muhammad al-Khasawanah, mentioned that Al-Khawarizmi was the first person who created praying time table and chose Baghdad as the standard of time. The table included the shadows of the sun at Zuhur time, at the beginning and end of Asar time written in "hisab jumali" (Abajadun hawazun) (Auni Muhammad al-Khasawanah, 1999;114-115, David A. King, 1993).

In the $3^{\text {rd }} \mathrm{H} / 9^{\text {th }} \mathrm{AD}$ century Ali bin Amajur improved al-Khawarizmi's work and made it more complete. Abu Ali al-Marrakushi even added the angular time and "rasdul qiblab". His model inspired other Islam astronomers who not only improved the table but they also involved arts in its appearance to create new-look models like the ones from Syria, Tunis, and Istanbul. History tells that ancient praying timetables presented as both a collective of data and an amazing art.

Nowadays some tables are under province-based calculation, while others are under city-based calculation with time conversion for other cities. Praying time schedule attached in the Ummul Qura, Egypt, and JAKIM of Malay calenders is a good example for the city-based calculation. And this is what happens with most Indonesian's tables. 


\section{The Fajr: In the Islam Mosaic and Modern Science}

As stated in the holy Quran and hadith, praying time coincides with the position of the sun in the sky. Therefore, when determining the time, the most important astronomical data $(z i j)$ is the position of the sun, in particular, its height (h) or distance of zenith (bu'du assumti) $\mathrm{Zm}=90^{\circ}-\mathrm{h}$. Morning twilight, sunrise, culmination, sunset, and evening twilight are closely related to the distance of zenith of the sun (Moedji Raharto, 2002:8).

Zuhur prayer begins when the whole solar disc has left meridian, about 2 minutes after at noon (Mohammad Ilyas, 1984). At top culmination, the center of the solar disc is at the meridian. However, for practical reason, median time is the middle time between sunrise and sunset.

Asar praying time has been a subject of difference in fiqih literatures because the phenomenon on which the calculation is based is unclear. In the above hadith, the prophet saw., was led to pray asar by angel Gabriel when the length of a shadow was the same as its object's height. Gabriel led prophet saw. the following day, however, when the length of the shadow was double. Although it can be concluded that asar time begins when the length of the shadow is the same as the height of its object, some different interpretations occur since the phenomenon is dependent upon seasons or yearly positions of the sun. In winter, the same occurance may or may not be reached at Zuhur time since the shadow will always be longer than its height.

The idea of considering the length of shadow at Zuhur time or twice the height of the object (in some European countries) is meant to anticipate the shadow's length in winter (Depag RI, 1997:29). The other takes Asar time as precisely in the middle between Zuhur and Magrib times regardless the distance of zenith of the sun as mentioned in the holy Quran QS Al-Baqarah verse 238 as-Salati al-Wusta (praying is in the middle). Some interpreters interprate it as Asar prayer. Based on this interpretation, Asar time is earlier than that in the existing schedule. 


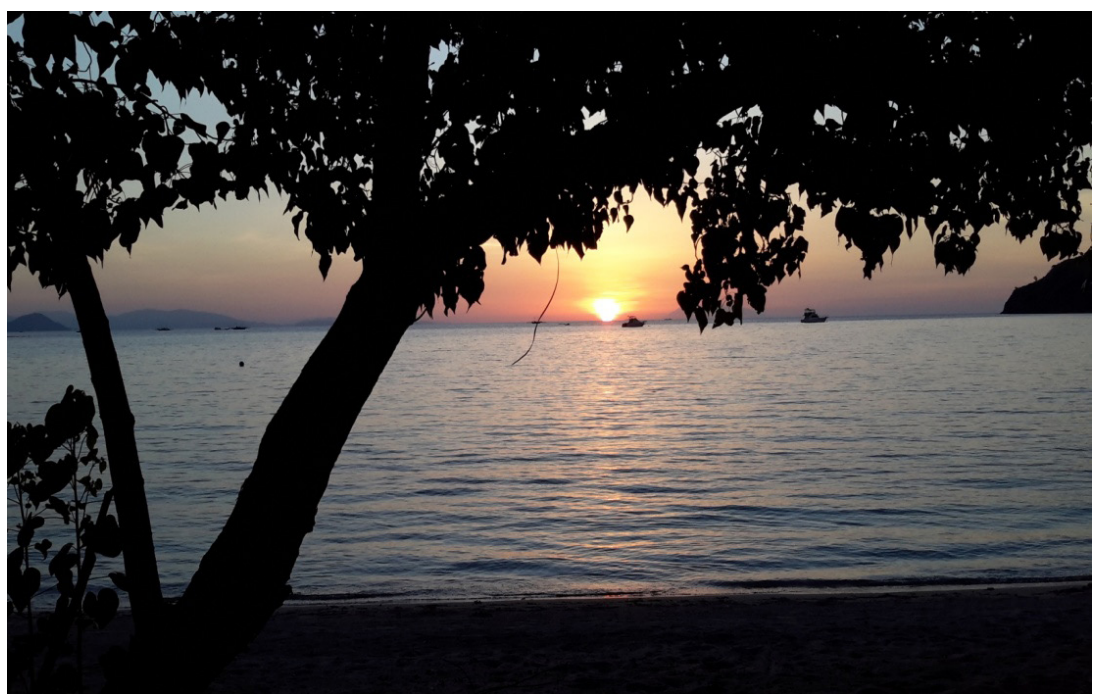

Magrib time in islamic astronomy means the sunset (ghurub), where the whole solar disc cannot be observed by the viewer. The diameter of the solar disc is 32 arc minutes, half of it, 16 arc minutes. Besides, there is a refraction (inkisar al-Jawwi) of light near the horizon, causing the sun looks higher than it actually is, which is assumed as 34 arc minutes. Correction of pseudodiameter (nishfu al-Quthr) of the sun and the refraction against the zenith distance of the sun when arising as well as setting is 50 arc minutes. Therefore, sunrise and sunset, astronomically, are defined as the zenith distance of the sun reaches $\mathrm{Zm}=90^{\circ} 50^{\prime}$. The definition goes well at sea level or at a place where the zenith distance of the sun is $\mathrm{Zm}=91$ degree when the level of horizon is included due to the observer's position 30 meters above sea level. In addition, Magrib time is two minutes after the sun sets since praying at sunset, sunrise, and top culmination is forbidden.

Isyak time begins when the western sky turns to reddish in colour (asy-Syafaq al-Ahmar) showing the beginning of the dark night (QS. Al-Isra' verse 78). This phenomenon is known as astronomical twilight. At this time the sun is $18^{\circ}$ below the west horizon or the zenith distance reaches $108^{\circ}$ (Saadoe'ddin Jambek, 1974:11).

Meanwhile, in the fiqih literature most ulamas agree that subuh prayer begins at true dawn and ends at sunrise (min tulu'i al-fajri assadiq ila tulu'i asy-syams). In practice, the concept of true dawn draws 
different opinions. In one occasion the fellow men were unable to recognize one another as they finished praying Subuh. It indicated that it was too dark to see clearly (ghalas). In another occasion, however, recognizing other's faces was possible which indicated the presence of sun light (isfar). Relating these occasions with Imamah Jibril hadith, we can easily understand that Imamah Jibril hadith is ' $a m$ while ghalas and isfar are special in nature. To cope with the problems, 'Am alMakhsus or 'Am Yuradu Bihi al-Khusus theories may be applied in spite of potential implication occurance.

The 5-time prayer a day was given after the prophet's Isra' and Mi'raj in $621 \mathrm{AD}$. Through the event and verses on prayers in the holy Quran, it can be infered that Subuh prayer had been ordered during Mecca era. Mecca is at $21^{\circ} 25^{\prime} \mathrm{NL}$ and 39\%49'EL. Surrounded by mountains, Mecca was a narrow valley with a very special building called Kakbah in the center. In the past, flood was a serius threat in raining season. The town has two seasons; winter from September to March reaching the coldest from December to February and summer from April with its peak in August. The temperature reaches as high as $55^{\circ} \mathrm{C}$ accompanied with hot wind in the day time. It is already bright after praying Subuh in summer, which contradicts that in winter. It indicates that ghalas occurs in winter and isfar in summer. The outlook is supported by Subuh praying timetable issued by Ummul Qurra calender as follows:

Table 1. Mecca Praying Time Table in Winter and in Summer

\begin{tabular}{|c|c|c|c|}
\hline \multicolumn{2}{|c|}{ Winter } & \multicolumn{2}{|c|}{ Summer } \\
\hline Month & Time & Month & Time \\
\hline September & $4.45-4.54$ & April & $4.55-4.27$ \\
\hline October & $4.54-5.04$ & May & $4.27-4.10$ \\
\hline November & $5.05-5.19$ & June & $4.09-4.12$ \\
\hline Decenber & $5.19-5.25$ & July & $4.12-4.28$ \\
\hline January & $5.25-5.38$ & August & $4.29-4.44$ \\
\hline February & $5.38-5.22$ & & \\
\hline March & $5.21-4.56$ & & \\
\hline
\end{tabular}

(Source: Taqwim Ummul Qurra) 
In the perpective of islamic astronomy the position of the sun at dawn is somewhat a problem. True fajr in the astronomy (falak ilmy) is believed as astronomical twilight where light starts to be seen in the East horizon just before the sun rises at $18^{\circ}$ below the horizon (zenith distance of the sun $=108^{\circ}$ ). This is followed by at-Tabataba'i (AtTabataba'i, tt, II:48), Mohammad Ilyas (Ilyas, 1984:144 - 145), Salih Muhammad al-Ujairy, Muhammad Ahmad Sulaiman, Muslim World League, and University of Science Karachi. Another opinion says that true fajr begins when the sun is $19^{\circ}$ or $20^{\circ}$ below horizon or the zenith distance of the sun is $109^{\circ}$ or $110^{\circ}$. The theory is supported by Ummul Qurra Committee and Al-Marrakushi (d. 660 H/1261AD).

Table 2. The Angular height of the sun at Subuh and Isyak time by Several Organizations

\begin{tabular}{|c|c|c|c|c|}
\hline \multirow{2}{*}{ No } & \multirow{2}{*}{ Organizations } & \multirow{2}{*}{ Countries of origin } & \multicolumn{2}{|c|}{$\begin{array}{c}\text { Depresion angle of } \\
\text { the sun }\end{array}$} \\
\hline & & & Subuh & Isyak \\
\hline 1 & $\begin{array}{l}\text { Egyption General } \\
\text { Authority of Survey } \\
\text { (Mesir) }\end{array}$ & $\begin{array}{l}\text { Afrika, Syria, Irak, } \\
\text { Lebanon }\end{array}$ & $-19,5^{0}$ & $-17,5^{0}$ \\
\hline 2 & $\begin{array}{l}\text { Islamic Society of } \\
\text { North America (ISNA) }\end{array}$ & $\begin{array}{l}\text { Canada, part of } \\
\text { America }\end{array}$ & $-15^{0}$ & $-15^{0}$ \\
\hline 3 & $\begin{array}{l}\text { Muslim World } \\
\text { League }\end{array}$ & $\begin{array}{l}\text { Europe, Far East, } \\
\text { Part of the United } \\
\text { States }\end{array}$ & $-18^{0}$ & $-17^{0}$ \\
\hline 4 & $\begin{array}{l}\text { Islamic University of } \\
\text { Karachi }\end{array}$ & $\begin{array}{l}\text { Pakistan, Bangladesh, } \\
\text { India, Afghanistan, } \\
\text { and part of Europe }\end{array}$ & $-18^{0}$ & $-18^{0}$ \\
\hline 5 & $\begin{array}{l}\text { Taqwim Um 'mul Quro } \\
\text { (Saudi Arabia) }\end{array}$ & Arabian Peninsula & $-19^{0}$ & $\begin{array}{l}90 \text { minutes } \\
\text { after } \\
\text { maghrib }\end{array}$ \\
\hline 6 & Syekh Taher Jalaluddin & $\begin{array}{l}\text { Indonesia, Singapore, } \\
\text { Malaysia, and Brunai } \\
\text { Darussalam }\end{array}$ & $-20^{\circ}$ & $-18^{0}$ \\
\hline
\end{tabular}


Table 3. The Zenith Distance of the Sun at Subuh and Isyak

\begin{tabular}{|l|c|c|}
\hline Astronomers & Isyak & Subuh \\
\hline Abu Raihan al-Biruni & $16-18$ & $15-18$ \\
\hline Al-Qaini & 17 & 17 \\
\hline $\begin{array}{l}\text { Ibnu Yunus, Al-Khalili, Ibn Syatir, Tusi, Mardeni, } \\
\text { Al-Muwaqqit di Syiria, Magrib, Mesir, dan Turkey }\end{array}$ & 17 & 19 \\
\hline Habash, Muadh, Ibn Haithim & 18 & 18 \\
\hline Al-Marrakushi, Tunis, dan Yaman & 16 & 20 \\
\hline Abu Abdullah al-Sayyid al-Moeti & 18 & 19 \\
\hline Abu Abdullah ibn Ibrahim ibn Riqam & 19 & 19 \\
\hline Chagmini, Barjandi, Kamili & 15 & 15 \\
\hline
\end{tabular}

The tables and other literatures reveal that the beginning of Subuh time is when the sun is $18^{\circ}$ high in the East horizon or when the zenith distance is 108o (Ayyad, 1988:75 - 77). In Indonesia in the 2000s, most people or the majority take Subuh time when the sun is $20^{\circ}$ below the true horizon like what is stated by the well-known Indonesian astronomer Saadoe'ddin Djambek, the so-called mujaddid al-hisab (the hisab thought revolusiner) of Indonesia. He stated that Subuh time began as the sunlight was seen below horizon in the East and ended as it rose. His opinion refers to astronomy that defines morning twilight as the position of the sun $20^{\circ}$ below the horizon in the East.

Another expert Abdur Rachim said that Subuh time was signaled by true dawn where the sun was $20^{\circ}$ below the horizon meaning the zenith distance of the sun was $110^{\circ}(90+20)$ (read Rachim, 1983:3940) and was ended at Syuruq (raise) i.e. $-01^{\circ}$. The two experts' thought seems to be influenced by Syaikh Taher Djalaluddin Azhari who wrote "Nakhbatu at-Taqrirati fi Hisabi al-Auqati". Syaikh Taher mentioned that Subuh time started when the sun was at $20^{\circ}$ below east horizon.

The theories mentioned above when being utilized result in different timetable. See the following table. 
Table 4. Praying Timetable of December 1, 2017 According to Current Theories for Jakarta

\begin{tabular}{|cccccccc|}
\hline & \multicolumn{7}{c|}{ DATA/THEORI BEING UTILIZED } \\
\cline { 2 - 8 } & Karachi & ISNA & MWL & U Qurra & Egyptian & $\begin{array}{c}\text { Ministry } \\
\text { of Religion } \\
\text { (Indonesia) }\end{array}$ & ISRN \\
\hline Zuhur & 11.42 & 11.42 & 11.42 & 11.42 & 11.42 & 11.42 & 11.42 \\
\hline Asar & 15.08 & 15.08 & 15.08 & 15.08 & 15.08 & 15.08 & 15.08 \\
\hline Magrib & 17.56 & 17.56 & 17.56 & 17.56 & 17.56 & 17.56 & 17.56 \\
\hline Isyak & 19.11 & 18.58 & 19.07 & 19.26 & 19.09 & 19.11 & 18.42 \\
\hline Subuh & 04.13 & 04.27 & 04.13 & 04.09 & 04.07 & 04.04 & 04.34 \\
\hline
\end{tabular}

The table shows 30 minutes difference between the earliest Subuh time 04.04 (Ministry of Religon) and the latest 04.34 (ISRN).

The difference in determining the position of the sun during true fajr lures experts to conduct researches. A doctor candidate at Kulliyatul 'Ulum (Faculty of Science) Al-Azhar University Kairo-Egypt 1407H/1988 AD Nabil Yusuf Hasanain wrote his dissertation entitled Dirasah al-Syafaq litahqiq Auqat as-Salah wa ruyati al-Hilal. In it he concluded Subuh time began as the sun reached $-14.5^{\circ}$ in average. Unfortunately his thesis is unreliable academically since it had never been examined due to his death before examination. For the sake of science and tecnology, Madinah alMalik Abdul Aziz together with 7 scientists went to a remote area, about $150 \mathrm{kms}$ from Riyadh, for the whole year $(1426 \mathrm{H} / 2005 \mathrm{AD})$ to conduct a research. The conclusion suggests that true dawn is at $14.6^{\circ}$ (Syaikh Mamduh Farhan al-Buhairi, 2010:217-218).

Khalid Shawkat participated by going to six countries (the US, Pakistan, the UK, Caribia, Australia, and New Zealand) and concluded that the angular time of fajr is between $-13.5^{\circ}$ and $-14^{\circ}$. With little factor safety $1 \mathrm{o}$ to $1.5 \mathrm{o}$, it became $-15 \mathrm{o}$. This theory is then adopted by Islamic Sociaty North America (ISNA) in determining the angle of the sun in relation with the beginning of Subuh and Isyak times (Syaikh Mamduh Farhan al-Buhairi, 2010:216-217) before it was changed to $-18^{\circ}$. Abed Alqader Aabid and Hani Dalee also did a study in Jordan and concluded $-16.5^{\circ}$ was the fajr angular time.

In Iran on February 17, 2008, true fajr was reported at 04:56:57 local time with the sun at $-18^{\circ}$ as recorded in the CCD. It coincides with 
the study by Abdul Haq (-18.9 ${ }^{\circ}$ and Nihayatur Rohmah (-18.10 ${ }^{\circ}$. From early April of 2013 till today, a discussion on angular true fajr occurs through a mailing list of the member of Islamic Crescent' Observation Project (ICOP). The discussion was stimulated by the statement of Sani Mustafa, a member of ICOP from Nigeria. Sani Mustafa cited al-Ghazali's opinion in his book Ihya' Ulumuddin (1989), vol. 1:227. Al-Ghazali wrote "dawn occurred when the moon rose on the 26/27 of each month in lunar calender".

In the discussion, the majority deny the authenticity of alGhazali's statement. According to Usman Dukku neither al-Quran nor as-Sunnah determins dawn based on a certain date. Despite the denial from the majority, Sani Mustafa insists on studying al-Ghazali's opinion comprehensively by putting syar'i and science aspects into consideration. Al-Ghazali admited that his father had spent years observing dawn. Apart from the pros and cons, the study on dawn involving a number of parties, particularly in Indonesia, is still relevant.

When making subuh praying timetable, most Islam countries employs an idea the sun is at -18 degree high with the exception of Indonesia, Malaysia, Singapore, and Brunei Darussalam that use -20 degree. Look at the following table.

Table 5. Praying Timetable in Several Countries on November 12, 2017

\begin{tabular}{|cccccccc|}
\hline No & Country & Subuh & Dawn & Zuhur & Asar & Magrib & Isyak \\
\hline 1 & Indonesia & 04.06 & - & 11.40 & 15.00 & 17.51 & 19.04 \\
\hline 2 & Singapore & 05.25 & 06.47 & 12.50 & 16.12 & 18.51 & 20.03 \\
\hline 3 & Malaysia & 05.40 & 06.57 & 13.00 & 16.22 & 18.58 & 20.10 \\
\hline 4 & Brunai & 04.47 & 06.07 & 12.04 & 15.27 & 18.02 & 19.14 \\
\hline 5 & Quwait & 04.47 & 06.09 & 11.32 & 14.33 & 16.55 & 18.17 \\
\hline 6 & Saudi & 05.14 & 06.32 & 12.08 & 15.20 & 17.44 & 19.12 \\
\hline 7 & Qatar & 04.23 & - & 11.18 & 14.25 & 16.47 & 18.17 \\
\hline 8 & Bahrain & 04.35 & - & 11.22 & 14.28 & 16.50 & 18.20 \\
\hline 9 & UEA & 05.18 & 06.34 & 12.10 & 15.17 & 17.39 & 18.56 \\
\hline 10 & Iraq & 05.05 & 06.31 & 11.46 & 14.41 & 17.02 & 18.32 \\
\hline 11 & Iran & 05.09 & 06.37 & 11.48 & 14.39 & 16.59 & 18.22 \\
\hline
\end{tabular}

(Source: adapted from various media and personal data) 


\section{Conclusion}

It can be summarized that different concept of fajr in the world of Islam arises for two reasons. Imamah Jibril hadith is considered too general in nature. Another reason is the existance of different interpretation on "ghalas" and "isfar" hadith due to the absence of reconstruction of the condition and weather in place of speaking. In addition, when interpreting the concept, moslem astronomers focus on the position of the sun. It is, therefore, time to study the beginning of subuh praying time by applying interdisciplinary approach to meet the demand from syar'i and modern science to reach a more valid and trustworthy result. In responding the polemic of on the beginning of dawn, it is good to consider what Syaikh Ridha Ahmad Shamadi alTailandi said. ".......man kind is not supposed to hurry blaming what experts are working on and are looking for the right answers. What he has to do is studying, discussing, and filtering it thoroughly to give the best result that does not provoke chaos in the moslem society."[]

\section{Reference}

Adwy, Mustafa ibn al-. Yawaqitu al-Falat $f i$ Mawaqit as-Salah, cet. 1, Mesir: Maktabah al-Bayan, t.t.

Amrulloh, Moh. Aff. "Penentuan Awal Waktu Shalat Subuh Menurut Kementerian Agama dan Aliran Salafi", Jurisdictie Jurnal Hukum dan Syariah, Volume 2, Nomor 2, Desember 2011.

Anonim. Waqai' Nadwah Tahqiq Mawaqit Salatay al-Fajr wa al-Isya', 1420/2000. Atmanto, Nugroho Eko. "Relevansi Konsep Fajar dan Senja dalam Kitab AlQanun al-Mas'udi bagi Penetapan Waktu Salat Isya’ dan Subuh", Jurnal Analisa, Volume 19, Nomor 01 Januari -Juni 2012.

At-Tabataba'i. Tafsir al-Mizan, Beirut: Dar al-Fikr, t.t.

Ayyad, Abdul Qawi Zaki. "Prayer Times at The Large Latitudes", dimuat di jurnal Islam Today, No. 6, VI/1408/1988.

Azhari, Susiknan. Ensiklopedi Hisab Rukyat, cet. III, Yogyakarta: Pustaka Pelajar, 2012. , "Awal Waktu Salat Subuh di Dunia Islam", makalah disampaikan dalam Konferensi Internasional Penyatuan Awal Waktu Salat Subuh Sebuah Upaya Pemenuhan Kriteria Fajar Sidik yang Objektif Ilmiah, diselenggarakan oleh Fakultas Syariah dan Hukum UIN Alauddin Makassar pada tanggal 15 Mei 2013.

Buhairi, Syaikh Mamduh Farhan al-. Koreksi Awal Waktu Subuh, cet. 1, Malang: Pustaka Qiblati, 2010. 
Dalee, Abed Alqader Aabid dan Hani. "Tahdid Mauid Hulul al-Fajr as-Sadiq fi alUrdun”, makalah dipresentasikan dalam "The Second Emirates Astronomical Conference” di Abu Dhabi Uni Emirat Arab, 30 Mei - 1 Juni 2010/16 - 18 Jumadil akhir 1431.

Haekal, Muhammad Husain. Sejarah Hidup Muhammad, Terjemahan Ali Audah, cet. X, Jakarta: Litera AntarNusa, 1989.

Harun, Muhammad Salih bin H.. Risalah Pedoman Bahagia Pada Membicarakan Sukatan Waktu dan Qiblah yan Mulia, Kuala Lumpur: Khazanah AlFataniah, 2005.

Ilyas, Mohammad, A Modern Guide to Islamic Calendar, Times \& Qibla, Kuala Lumpur: Berita Publishing, 1984.

Ismail. "Metode Penentuan Awal Waktu Salat dalam Perspektif Ilmu Falak", Jurnal Ilmiah Islam Futura, Vol. 14, No. 2, Februari 2015.

Jabr, Sa'di Husain Ali. Figh al-Imam Abiy Thaur, cet. 1, Beirut: Muassasah arRisalah, 1983.

Jailani, Zubair Umar al-. Al-Khulashah al-Wafiyyah fi al-Falak bijadawil alLugharitimiyyah, tt. Menara Kudus.

Jambek, Saadoe'ddin. Shalat dan Puasa di Daerah Kutub, Cet. 1, Jakarta: Bulan Bintang, 1974.

Khasawanah, Auni Muhammad al-. Tatbiqatu Ilm al-Falak fi asy-Syariati alIslamiyati, 1420/1999.

King, David A.. Astronomy in The Service of Islam, cet. 1, USA: Variorum, 1993.

Miftahi, Yaqub Ahmed. Fajar and Isha, cet. 1, London: Hizbul Ulama, 1426/2005.

Rachim, Abdur. Ilmu Falak, cet. 1, Yogyakarta: Liberty, 1983.

Rohmah, Nihayatur. Syafaq \& Fajar Verifikasi dengan Aplikasi Fotometri: Tinjauan Syar’i dan Astronomi, cet. I, Yogyakarta: Lintang Rasi Aksara Book, 2012.

Sadali, Hardi Bin Mohamad. Prosedur Waktu Solat Menurut Fuqaha dan Ilmu Falak: Pelaksanaannya di Pulau Pinang, cet. 2, Jabatan Mufti Negeri Pulau Pinang, 2009.

Sulaiman, Muhammad Ahmad. Sibahah Fadlaiyah fi Afaq Ilm Al-Falak, cet. 1, Kuwait: Maktabah al-Ujairy, 1420/1999.

Syaikh Shofiyurrahman Al-Mubarakfuri. Ar-Rahiq al-Makhtum, cet. I, Riyad: Dar as-Salam, $1418 \mathrm{H}$.

Syekh Abdul Mun'im az-Zain. Al-Mawaqit, cet. I, Dakar: Dar al-Mahaja, $1432 / 2011$.

Ujairy, Salih Muhammad al-. Al-Mawaqit wa al-Qiblah, cet. 1, Kuwait, t.p, $1408 / 1988$.

Yahya, Fathurrohman. Antara Mekkah \& Madinah, cet. 1, Jakarta: Erlangga, 2009. 
232 - Susiknan Azhari

Zainal, Baharrudin. Ilmu Falak, edisi Kedua, Kuala Lumpur: Dewan Bahasa dan Pustaka, 2004.

Zuhaily, Wahbah Az-. Al-Fiqh al-Islamy wa Adillatuh, cet. III, Damaskus: Dar al-Fikr, 1989.

Susiknan Azhari, Faculty of Sharia and Law State Islamic University Sunan Kalijaga Yogyakarta. E-mail: susiknanazhari69@gmail.com 


\section{Mhliam}

AHKAM Jurnal Ilmu Syariah (ISSN: 1412-4734/E-ISSN: 2407-8646) is a periodical scientific journal published by Faculty of Sharia and Law of Syarif Hidayatullah State Islamic University Jakarta in collaboration with Indonesian Scientist and Sharia Scholar Association (HISSI). This journal specifically examines the science of sharia and obtains to present various results of current and eminence scientific research. The administrators receive articles as contributions Sharia and Islamic law disciplines from scientists, scholars, professionals, and researchers to be published and disseminated. The article will be situated in a selection mechanism, a review of proved reders, and a strict editing process. All articles published in this Journal are based on the views of the authors, but they do not represent the authors' journals or affiliated institutions.

AHKAM has been accredited based on the determination of Director General of Research Reinforcement and Development, Research, and Technology Ministry of Higher Education of Republic of Indonesia, No. 36/a/E/KPT/2016 (valid until 2021). 